\title{
Intercultural Theology and Missiology
}

\author{
STEFAN PAAS
}

Vrije Universiteit

Amsterdam

\author{
Theologische Universiteit \\ Kampen
}

\section{Spiritual Experience and Theology}

In his reflections on the spirituality of liberation theology Gustavo Gutierrez writes about the relationship between theology and spirituality. Taking his point of departure in Anselm's classic definition, Gutierrez asserts that Christian theology is an attempt to understand what Christians believe. "The experience of faith is presented as the starting point of all testimony and reflection." This is also where theology proper starts, not as a label for hermeneutical, historical, and social scientific academic disciplines concentrated on the study of religion, but as an intentional construction of Christian faith that can be presented to those inside and outside the Church. Gutierrez affirms: "The solidity and energy of theological thought depend precisely on the spiritual experience that supports it." This experience, in turn, is "particular": it is had "by concrete persons living at a particular time." It is "both proper to them and yet communicable to others" (Gutierrez 1984, 36-37).

\section{Intercultural Theology and Mission}

These ideas express the core element of what is "intercultural" about theology. Due to its missionary nature, Christianity has emerged in our times as an interlocking network of local experiences generating as many theologies - distinct yet communicable to others. Thus, I consider intercultural theology the logical follow-up to mission. As Andrew Walls puts it: "[T] he very universality of the Gospel, the fact that it is for everyone, leads to a variety of perceptions and applications of it" (Walls 1996: 46). The original "trans"- or "cross"-cultural movement of mission must inevitably give way to the "inter"-cultural movement of the fellowship of those who have responded to the Gospel. However, even this pattern of "cross" followed by "inter" may not grasp the matter entirely. The missionary encounter creates grassroots experiences which transcend the socio-historical context of those who believe the Gospel while at the same time accepting this context as the only authentic way in which the Gospel can be received and understood. Thus, the missionary encounter in itself is intercultural 
from its very beginning, since it always includes an interaction between the old and the new, the known and the unknown, God and the gods, the traditional and the eschatological. Therefore, intercultural theology is like the tree that grows from the seed of mission; it is the unpacking of what was given in the first missionary encounter already and taking it to its logical conclusion. To be sure, the history of mission amply testifies to the fact that this "growth" or "unpacking" is a far from harmonious process. Recognizing the intercultural nature of mission and allowing this nature to unfold requires a fair assessment of the imbalance of power which has almost always been the context of historical missions. A decolonization of missiology and missionary practice is therefore not merely a consequence of changed sensitivities or late modern philosophy but is part and parcel of what mission is all about: the creation and recognition of authentic, localized Christian experience that is "particular" yet "communicable."

\section{The "Cultural" in "Intercultural Theology"}

That said, in our rapidly changing world, intercultural theology may still carry too many colonial overtones. Taken at face value, the word seems to assume that the world is divided into "cultures" that form a more or less stable background for theologies that result from it. This assumption runs the risk of framing differences between Christians along "orientalizing" or "exoticizing" lines as a consequence of "culture." After all, what is usually framed in terms of "culture" may often just as well be framed in terms of "language," "gender," "class," "age," "professional occupation," "education level," or even "moral insensitivity" and "racism." All these factors are part of profound spiritual experiences and can be used to explain and explore human differences. While humans are undeniably (also) cultural beings, the missionary intervention has the potential to destabilize cultures or to mix them. Moreover, in a world of migration, diaspora, and globalizing trends, it remains to be seen as to what extent "culture"- at least "thick" definitions of culture-will be a suitable category for explaining differences between people. Increasingly, Christians from different cultures are living together in shared spaces - often in the secularized cities of the West - thus creating the possibility of having shared experiences and spiritualities. And globalized varieties of Christianity such as Neo-Pentecostalism, seem able to take root virtually everywhere among very different cultures and classes, thus creating what may be seen from one perspective as the first truly intercultural form of Christianity, while on the other hand representing a global religious monoculture. Altogether, the term intercultural theology points to a past when Christian mission

(C) Equinox Publishing Ltd. 2017

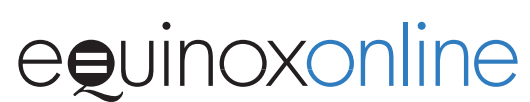


was done transculturally with a Western bias, correcting this past at the same time. In an age of "mission from everywhere to everywhere," without clear centres, we may have to design concepts which are more open towards the new realities - like "world theology" or "planetary theology."

An additional objection to the term "intercultural theology" relates to my own research into Christian mission in the secular West. In my experience, the concept of "culture" invites theologians to employ large, rather theoretical and abstract frameworks in explaining differences between Christians from different continents or between Christians and their non-Christian fellow citizens. For example, theological or ethical disagreement between "native" European Christians and immigrant Christians from, say, Africa living in Europe is often explained by concepts like "Enlightenment" (Africans not having experienced it), "enchantment," or "modernity." Such concepts may provide some type of explanation, but they usually do not help Christians on the ground achieve any common understanding and do "intercultural" theology together. Again, people are "locked," as it were, inside their real or imaginary socio-historical backgrounds, often with the tacit assumption that "they" are not yet where "we" have already arrived. In other words, differences between Christians are framed in terms of intellectual histories or large and abstract social developments, rather than in terms of different local experiences or - even more prosaic - of personality, education, or character. It may have to do with my lack of formal training in systematic theology, but I prefer a more inductive approach to what happens theologically when Christians live and work together in shared contexts, especially those contexts influenced by globalization and migration. The current trend in theology towards what Jeff Astley calls "ordinary theology" (Astley 2003), and concurrent research methods like ethnography, are promising in this regard.

\section{Examples of Local Experience}

While these local encounters between Christians with different spiritualities can be extremely complicated (for example, around issues of sexuality), they can lead to inspiring new questions and experiences. While discussing the narrative of Jacob stealing his brother Esau's birth-right with students in Zomba, Malawi, where I taught Old Testament exegesis, I was struck by the students' complete sympathy with Jacob. After all, Jacob's trick did not sit well with my inbred beliefs of fair play and transparency. However, the students explained to me how in their own very socially stratified society, the "firstborn" was almost always beyond criticism. In

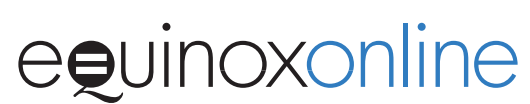


other words, he was free to bully his younger brothers around whenever he pleased. The only way for a younger brother to escape this was to outsmart the firstborn son - as Jacob did. I was introduced by my students to a world where - just like in ancient Israel - the institution of the "firstborn" was an experienced reality, together with many other aspects that form the background of biblical narratives, such as tribes, circumcision, sacrifices, and so on. When preparing my dissertation in Old Testament Studies I had read many decent German scholars who assured their readers that the constant difficulties readers of the Old Testament throughout history had experienced (Marcion, Mani, Origen, Harnack, etc.) was a sure sign that the problem lay in the Scriptures itself rather than in the readers. The African experience gave me a new perspective, as this was the first time that I met a readership that experienced no difficulty at all in "owning" the Biblical texts. I believe that this experience could happen only by participating in this context and sharing space with these students, allowing myself to become their student rather than their teacher. It is an experience that must be taken seriously as a source of theology, rather than prematurely "othered" away as a "cultural" perspective or-even worse - as a perspective of those who have not yet gone through processes of modernization and individualization.

A more complicated example is communicated by Claudia WährischOblau in her study of African Pentecostal missionaries in Germany. Having become curious about what made the Germans "tick," they received an extended seminar by a German Professor on the philosophies of Feuerbach, Marx, and Freud. Their response was a prayer meeting in which they "were going to wage spiritual warfare against the spirits of Feuerbach, Marx and Freud." The researcher remembers the deep shock she felt, sure that the Germans had completely failed to make the participants understand the meaning of Feuerbach, Marx and Freud. However, the colleague who had been teaching "wondered aloud whether perhaps an exorcism of the spirit of religious criticism might be exactly what Germany needed" (Währisch-Oblau 2009, 300). Clearly, an example like this is not easy to analyse or even to understand. Feelings of shock or alienation may very well be part of a shared spiritual experience. However, the humble curiosity expressed by the researcher and her colleague may open up a path to explore and work out an intercultural theology together, rather than keep the experience at arm's length as an instance of a bygone "enchanted" worldview. 


\section{Intercultural Theology and Missiology}

Examples like these raise again the question of the relationship between missiology and intercultural theology. Above I defended a relationship in which mission is the seed out of which intercultural theology grows. Missiology, therefore, may be considered to be the discipline that reflects on the entire process (or cycle?) in which the Gospel seed is sown, grows into a mature tree that may very well produce fruits of mission againas the example of Pentecostal pastors in Germany demonstrates. I do not suggest this in an encyclopaedic way, as if missiology should be the umbrella under which evangelism and intercultural theology are captured. We might just as well construct the relationship the other way around: missiology as dependent on the intercultural awareness that the Gospel is there to be offered to all people from all cultures. Here, intercultural theology may form a healthy correction to some trends among Western theologians to subsume missiology exclusively under a redefined intercultural theology, out of embarrassment with the painful history of Western colonial missions. Intercultural theology, in this approach, is defined as a discipline that reflects, first, on the relationship between Christianity and non-Christian religions or worldviews, and, second, on the relationship between Western Christianity and its non-Western cultural varieties. ${ }^{1}$ My problem with this is twofold.

First, I find it hard to see how exactly mutuality is possible in intercultural theology with respect to the theologizing of Christians and non-Christians together. Using the term "intercultural theology" for this type of interaction, rather than "religious dialogue" or an equivalent, sounds rather ideological, as this apparently assumes that Christians and non-Christians can work together towards a supra-religious theology or that Christian theology can draw on various religious sources considered to be of equal value ("interreligious theology" or "comparative theology"). All this is highly contestable from a Christian theological point of view. Limiting the concept of intercultural theology to theological interaction between Christians therefore seems to be a more promising course.

My second problem with this approach, apart from its awkward positioning of Western Christianity as the cultural centre of World Christianity, is its lack of sensitivity to what the intercultural character of Christianity means for missiology. After all, mission has become a

1 See, for example, the position paper by the missiological section of the Wissenschaftliche Gesellschaft für Theologie (WGTh) and the board of the Deutsche Gesellschaft für Missionswissenschaf 2005.

(C) Equinox Publishing Ltd. 2017

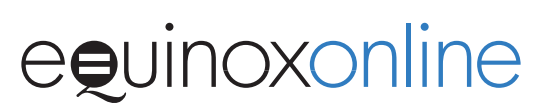


movement without centres, a movement from everywhere to everywhere (Walls 2008; Walls 2002,72-81). Christianity has found a home in many cultures, and the world is no longer a world of "senders" and "receivers." What gives Western Christians the right to redefine missiology solely based on their own experiences without taking into regard how deeply interested in mission many Christians outside the West are? (Oborji 2008: 113-14). Missiology must become a truly intercultural theological discipline, processing the insights and experiences of Christians from all over the planet, including the vast majority who find that evangelism is the heart of mission. Such an intercultural missiology will take mission seriously as transcultural witness, proclamation, and persuasion (Feldtkeller 2013). The idea of intercultural unity between people is first and foremost embodied by mission, by the simple yet revolutionary thought that human beings not only have the right to receive the truth that has been given to the few but also that they are in every respect capable of understanding, receiving, and processing this truth. As soon as this idea is abandoned, mission stops and tribalism begins.

\section{References}

Astley, Jeff. 2003. Ordinary Theology: Looking, Listening, and Learning in Theology. Ashgate: Aldershot.

Feldtkeller, Andreas. 2013. "Missionswissenschaft und Interkulturelle Theologie." Theologische Literaturzeitung 138: 3-12.

Gutierrez, Gustavo. 1984. We Drink from Our Own Wells: The Spiritual Journey of a People. Translated by Matthew J. O'Connell. London: SCM.

Oborji, Francis Anekwe. 2008. "Missiology in Relation to Intercultural Theology and Religious Studies," Mission Studies 25:113-114. https://doi. org/10.1163/157338308X293981

Währisch-Oblau, Claudia. 2009. The Missionary Self-Perception of Pentecostal/Charismatic Church Leaders from the Global South in Europe: Bringing Back the Gospel. Leiden: Brill. https://doi.org/10.1163/ ej.9789004175082.i-430

Walls, Andrew F. 2008. "Afterword: Christian Mission in a Five-hundred Year Context" In Mission in the 21st Century: Exploring the Five Marks of Global Mission, edited by Andrew Walls and Cathy Ross, 193-2005. Maryknoll: Orbis. https://doi.org/10.5810/ kentucky/9780813125152.003.0013

_1996. The Missionary Movement in Christian History: Studies in the Transmission of Faith. Maryknoll: Orbis.

(C) Equinox Publishing Ltd. 2017

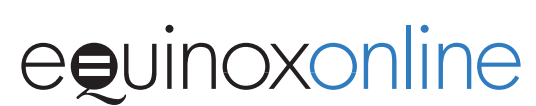


Walls, Andrew F., editor. 2002. The Cross-Cultural Process in Christian History. Maryknoll: Orbis.

Wissenschaftliche Gesellschaft für Theologie (WGTh) and the board of the Deutsche Gesellschaft für Missionswissenschaft. 2005. "Missionswissenschaft als Interkulturelle Theologie und ihr Verhältnis zur Religionswissenschaft." Zeitschrift für Mission 31: 376-382.

Stefan Paas is Professor of Missiology and Intercultural Theology at Vrije Universiteit Amsterdam and Professor of Missiology at Theologische Universiteit Kampen. Email: s.paas@vu.nl 